\title{
Effect of Fortified Iron in Dahi on Haematological Parameters in Rats
}

\author{
Priyanka $^{1}$, Anjum ${ }^{2 *}$, C.S. Shashi Kumar ${ }^{3}$ and Narasimha Murthy ${ }^{4}$ \\ ${ }^{1}$ Department of Dairy Chemistry, Dairy Science College, Mahagaon Cross, Gulbarga, \\ Karnataka Veterinary Animal and Fisheries Sciences University (Gulbarga), \\ Karnataka, India \\ ${ }^{2}$ Department of Dairy Chemistry, Dairy Science College, Karnataka Veterinary Animal and \\ Fisheries Sciences University (KVAFSU), Hebbal, Bengaluru-24, Karnataka, India \\ ${ }^{3}$ Department of Dairy Technology, Dairy Science College, Karnataka Veterinary Animal and \\ Fisheries Sciences University, Karnataka, India \\ ${ }^{4}$ Dairy Science College, Karnataka Veterinary Animal and Fisheries Sciences University \\ (KVAFSU), Hebbal, Bengaluru-24, Karnataka, India \\ *Corresponding author
}

A B S T R A C T

\begin{tabular}{|l|}
\hline Ke y w or d s \\
Dahi, Haemoglobin, \\
Blood iron, Iron \\
fortification
\end{tabular}

Iron is an essential micro-mineral in human nutrition. It is a mineral found in every cell of the body and required to make part of blood cell. It participates as a catalyst in several metabolic reactions. As a component of haemoglobin, myoglobin, cytochrome and other proteins, iron plays an important role in the transport, storage and utilization of oxygen and cellular proliferation. In this study, an attempt was made to prepare dahi by using $1 \%$ starter culture, fortified with iron by using ferrous lactate @ $40 \mathrm{mg} / \mathrm{kg} \mathrm{milk}$. This level showed sensory attributes acceptance, physico-chemical viz., acidity, total solids, fat and protein parameters. Animal experimentation by feeding rats with iron fortified dahi revealed increased gain in body weight. Haemoglobin and blood iron concentrations showed tremendous increase in rats fed with fortified dahi than in animals fed with unfortified dahi. From the present study, it can be concluded that, iron fortified dahi can be used effectively to combat iron deficiency anaemia. Fortified dahi showed improved absorption and helped to overcome iron deficient anaemic conditions.

\section{Introduction}

Dahi is a very nourishing food. It has gained widespread consumer acceptance. It is an excellent source of calcium and protein but as is typical of all dairy products, contains very little iron. Iron $(\mathrm{Fe})$ is an essential micromineral in human nutrition. It is a mineral found in every cell of the body to make part of blood cells. The total content of iron in an adult body is $3-5 \mathrm{~g}$. About $70 \%$ of this occurs in the erythrocytes of blood as a constituent of hemoglobin. At least 5\% of body iron is present in myoglobin of muscle. Heme is the most predominant iron containing substance. It is a constituent of several proteins/enzymeshemoglobin, myoglobin, cytochromes, xanthine oxidase, catalase and peroxidase. 
Iron deficiency in the human body is one of the most common health issues, occurring in infants and children solely dependent on milk and milk products, because of fast growth and low dietary intake, this problem can be effectively prevented by addition or fortification of iron. Therefore, dairy products are logical vehicles for iron fortification because they are widely consumed by all the classes of people in the world.

\section{Materials and Methods}

Fresh milk was obtained from Student Experimental Dairy Plant (SEDP), of Karnataka Veterinary Animal and Fisheries Sciences University (KVAFSU), of Hebbal, Bengaluru-24. For standardization of cow milk (fat $3.5 \%$ and SNF 8.5\%), Nandini cream and spray dried Nandini skim milk powder were used. Mixed starter culture, consisted of Streptococcus lactis, Streptococcus diacetylactis along with the species of Lactobacillus such as Lactobacillus bulgaricus and Streptococcus thermophillus. In the ratio of 1:1 were procured from the Dept. of Dairy Microbiology, KVAFSU, Bengaluru-24.

Food grade salt was used. Ferrous lactate (Sigma-Aldrich chemicals company, Spain). A total of 12 adult male albino rats weighing about 100-110 g were used in experiment. Animals were kept under normal laboratory conditions for 1 week before the initiation of the experiment. Rats were allowed free access of water and fed on uniformly diet.

In order to achieve the accuracy and the complete distribution of fortified ferrous lactate, preparation of $10000 \mathrm{mg} / \mathrm{kg}$. of iron was prepared by dissolving this salt in distilled water. The standardized milk was preheated to $60^{\circ} \mathrm{C}$ and homogenized at 2500 psi at first stage and 500 psi at second stage. Then milk was heated to $95^{\circ} \mathrm{C}$ for $15 \mathrm{~min}$. During heating milk was stirred continuously with the help of stirrer to avoid formation of cream layer, cooled to $37^{\circ} \mathrm{C}$, divided into two equal portions: The first portion served as control. The rest portion was fortified separately with ferrous lactate at a level of 20, 30 and 40mg iron/ $\mathrm{kg}$ milk and inoculated with $1 \%$ dahi culture and incubated for 17 hours (Khedkar $e t$ al., 2014).

Dahi was organoleptically evaluated according to the standard score card of a total of 25 points for assessing the degree of firmness, whey separation, body and texture, flavour. $\mathrm{pH}$ of the sample was measured using a digital $\mathrm{pH}$ meter (Chemi line Pvt. Ltd.) at $25^{\circ} \mathrm{C}$. Acidity, protein concentration, fat, total solids, ash and moisture content of dahi was estimated as per the standard procedure IS: SP 18 (Part XI) 1981. MSNF content in milk was computed by using ISI Lactometer by using the following formula

$\operatorname{SNF}(\%)=\frac{C L R}{4}+0.25 F+0.34$

Where,

CLR-Corrected Lactometer Reading

F-Fat (content in per cent)

Six rats served as a normal control (unfortified dahi fed) and other six rats were fed with fortified dahi. After $28^{\text {th }}$ day blood was collected from the experimental animals in clean, sterilized and labelled test tubes, by retro-orbital plexus puncture method using microhaematocrit capillary tubes.

To perform subsequent biochemical parameters such as Haemoglobin and Blood iron were tested as per the AOAC (1980) method. The results (average of 3 trials) were analyzed statistically for test of significance by using ANOVA as per SPSS10.0software package and MS Excel 2007. 


\section{Results and Discussion}

Effect of different levels of starter culture on physico-chemical properties of Dahi

Addition of starter culture at different levels $(1,1.5$ and $2 \%)$ showed no significant difference in total solids, fat, protein and iron and there is a significant difference in $\mathrm{pH}$ and acidity as expected. It is evident from the results (Table 1) that increase in starter culture addition resulted in reduction in $\mathrm{pH}$ (4.2). Reduction in $\mathrm{pH}$ is due to increase in lactic acid production from lactose fermentation by dahi cultures.

Increase in starter culture level caused increase in acidity of experimental samples. The results are in agreement with the findings of Hossain et al., (2012) who found that acidity of fruit dahi was significantly increased due to the addition of higher levels of starter. Kale et al., (2011) prepared value added stirred dahi using different types of fruits pulp and observed that acidity content of dahi increased due to the addition of fruits pulp. It is evident from the results total solids content of $1,1.5$ and $2 \%$ starter culture added dahi samples were statistically non-significant which was seen among the total solids content of different dahi.

The fat content of different dahi samples showed no significant differences of the fat content. It could be seen from table $1 \mathrm{SNF}$ content of $1,1.5$ and $2 \%$ starter culture added dahi samples were statistically non-significant difference among different dahi samples. The protein content of present investigation agrees with the findings of Hossain et al., (2012).

The native iron content of $1,1.5$ and $2 \%$ starter culture added samples were statistically non-significant which was seen from the iron concentration of different dahi samples.
Influence of different levels of starter culture on sensory attributes of dahi

The effect of different levels of starter culture on sensory attributes of dahi (Table 2) containing different levels of starter culture was subjected for organoleptic evaluation by a panel of Judges. Sensory scores for the dahi were graded organoleptically on a 25-point hedonic scale.

From table 2 it can be observed score for dahi made from $1 \%$ starter culture bagged highest score. It was observed that there is increased sourness due to increase in the level of addition of starter culture resulted in increased production of lactic acid is due to utilization of principal milk sugar lactose by starter organisms at a faster rate., reduction of flavour score with increase in starter culture addition. Statistically it is proved that significant difference exists between samples and control as well as between the samples with different levels of starter culture.

The appearance was good for dahi inoculated with $1 \%$ starter culture and scored maximum of 4.50. Increase starter culture addition caused increase in acidity and wheying off that in turn reduced the score for appearance.

The dahi made from 2\% starter culture exhibited of lack uniform appearance due to wheying off. This defect led to reduction in sensory score for appearance and it scored 4.33 .

Body and texture score was highest for dahi made by using $1 \%$ starter culture. This is due to the fact that, dahi was practically free from whey separation and body was firm with uniform texture. Increased starter level resulted in loose body due to presence of more whey pockets. Hence, dahi made by using $1 \%$ starter culture was employed for experimental studies. 
Table.1 Influence of different levels of starter culture on physico-chemical properties of dahi

\begin{tabular}{|c|c|c|c|c|c|c|}
\hline $\begin{array}{c}\text { Level of starter } \\
\text { culture }\end{array}$ & $\mathbf{p H}$ & $\begin{array}{c}\text { Acidity \% } \\
\text { Lactic acid }\end{array}$ & $\begin{array}{c}\text { Total } \\
\text { Solids \% }\end{array}$ & $\begin{array}{c}\text { Fat } \\
\text { \% }\end{array}$ & $\begin{array}{c}\text { Protein } \\
\%\end{array}$ & $\begin{array}{c}\text { Iron } \\
\mathbf{m g} / \mathbf{1 0 0 g}\end{array}$ \\
\hline Control (0.5\%) & 4.42 & 0.74 & 11.8 & 3.3 & 3.5 & 0.1 \\
\hline $1 \%$ & 4.40 & 0.76 & 11.77 & 3.2 & 3.4 & 0.1 \\
\hline $1.5 \%$ & 4.30 & 0.78 & 11.8 & 3.3 & 3.6 & 0.12 \\
\hline $\mathbf{2 \%}$ & 4.20 & 0.80 & 11.83 & 3.3 & 3.5 & 0.12 \\
\hline CD $(\mathbf{p} \leq \mathbf{0 . 0 5})$ & $\mathbf{0 . 0 3}$ & $\mathbf{0 . 0 2}$ & $\mathbf{0 . 1 5}$ & $\mathbf{0 . 1 1}$ & $\mathbf{0 . 1 4}$ & $\mathbf{0 . 0 6}$ \\
\hline
\end{tabular}

All values are average of three trials

Table.2 Effect of different levels of starter culture on sensory attributes* of dahi

\begin{tabular}{|c|c|c|c|c|c|c|}
$\begin{array}{c}\text { Level of } \\
\text { starter } \\
\text { culture (\%) }\end{array}$ & $\begin{array}{c}\text { Flavour } \\
\mathbf{( 1 0 )}\end{array}$ & $\begin{array}{c}\text { Sourness } \\
\mathbf{( 2 )}\end{array}$ & $\begin{array}{c}\text { Appearance } \\
\mathbf{( 5 )}\end{array}$ & $\begin{array}{c}\text { Sody and } \\
\text { Texture (5) }\end{array}$ & $\begin{array}{c}\text { Closure and } \\
\text { Container (3) }\end{array}$ & $\begin{array}{c}\text { Total } \\
(\mathbf{2 5})\end{array}$ \\
\hline $\begin{array}{c}\text { Control } \\
(\mathbf{0 . 5})\end{array}$ & 8.66 & 1.58 & 4.41 & 3.90 & 2.80 & 21.35 \\
\hline 1.0 & 9.16 & 1.50 & 4.50 & 4.83 & 2.85 & 22.84 \\
\hline 1.5 & 8.50 & 1.66 & 4.41 & 4.50 & 2.83 & 21.90 \\
\hline 2.0 & 8.40 & 1.75 & 4.33 & 4.66 & 2.83 & 21.97 \\
\hline CD $(\mathbf{P} \leq \mathbf{0 . 0 5})$ & $\mathbf{0 . 9 0}$ & $\mathbf{0 . 5 1}$ & $\mathbf{0 . 8 6}$ & $\mathbf{0 . 7 7}$ & $\mathbf{0 . 0 1}$ & $\mathbf{0 . 9 0}$ \\
\hline
\end{tabular}

All values are average of three trials

*Scores obtained based on 25-point hedonic scale.

Table.3 Effect of different levels of iron on sensory attributes of dahi

\begin{tabular}{|c|c|c|c|c|c|c|}
\hline \multirow{2}{*}{$\begin{array}{l}\text { Level of iron } \\
\text { (mg iron/kg } \\
\text { milk) }\end{array}$} & \multicolumn{6}{|c|}{ Sensory attributes (Max. score: 25.00) } \\
\hline & $\begin{array}{c}\text { Flavour } \\
\text { (10) }\end{array}$ & $\begin{array}{l}\text { Sourness } \\
\text { (2) }\end{array}$ & $\begin{array}{c}\text { Appearance } \\
\text { (5) }\end{array}$ & $\begin{array}{c}\text { Body \& } \\
\text { Texture (5) }\end{array}$ & $\begin{array}{c}\text { Closure \& } \\
\text { Container (3) }\end{array}$ & $\begin{array}{l}\text { Total } \\
\text { (25) }\end{array}$ \\
\hline Control & 9.16 & 1.75 & 4.33 & 4.16 & 2.81 & 22.21 \\
\hline 20 & 9.25 & 1.83 & 4.16 & 4.33 & 2.83 & 22.4 \\
\hline 30 & 9.08 & 1.90 & 4.41 & 4.58 & 2.82 & 22.79 \\
\hline 40 & 9.41 & 1.50 & 4.58 & 4.66 & 2.84 & 22.99 \\
\hline
\end{tabular}

All values are average of three trials *Scores graded based on 25-point hedonic scale.

Table.4 Effect of Iron on Haemoglobin, blood iron concentration in rats

\begin{tabular}{|c|c|c|}
\hline Type of diet & Haemoglobin (\%) & Blood iron (\% $\mathbf{m g})$ \\
\hline Control & 12.47 & 35.82 \\
\hline D & 13.2 & 37.92 \\
\hline D1 & 16.1 & 46.25 \\
\hline
\end{tabular}

All values are average of six trials at the end of $4^{\text {th }}$ week of feeding period. Control; D: Unfortified dahi; D1: Dahi fortified with iron (40 mg/kg). 
Effect of different levels of iron fortification on Physico-chemical properties of dahi

Unfortified dahi showed $\mathrm{pH}$, acidity, total solids, fat, SNF, protein contents as 4.4, 0.76 percent lactic acid, 11.77, 3.2, 8.57 and 3.4 percent respectively.

Fortification of dahi with iron salts at the rate of 20,30 and $40 \mathrm{mg} / \mathrm{kg}$ had no noticeable effect on physico-chemical properties such as $\mathrm{pH}$, acidity, total solids, fat, SNF and protein, i.e., it remains almost similar when compared to unfortified dahi.

\section{Influence of different levels of iron on sensory attributes of dahi}

An ideally dahi shall possess a pleasant, clean acid flavor. It shall be free from undesirable flavors such as: bitter, rancid, oxidized, stale, yeasty and unclean. As could be seen from table 3 the best result for flavour was obtained for iron fortification at $40 \mathrm{mg} / \mathrm{kg}$ level. Because when iron fortified dahi at 20, 30 $\mathrm{mg} / \mathrm{kg}$ was subjected for sensory evaluation they have scored less point because of whey separation and high degree of souring. Higher fortification $(>40 \mathrm{mg} / \mathrm{kg})$ yielded dahi with metallic flavour. Hence, for the experimental studies an optimum level of $40 \mathrm{mg}$ of iron $/ \mathrm{kg}$ dahi is employed.

As could be seen from the results for appearance the highest score for appearance was obtained for dahi fortified iron at $40 \mathrm{mg} /$ $\mathrm{kg}$ level when compared with iron fortified dahi 20 and $30 \mathrm{mg} / \mathrm{kg}$ level. Appearance of dahi fortified with iron was not much affected by the different levels of iron which appeared natural dahi colour i.e., control samples. These were in agreement with those given by El-kholy (2011) and El-Din et al., (2012). Natural dahi shall posses a firm, custard- like body with a smooth homogeneous texture.
The best results for body and texture was observed in dahi fortified with iron at 40 $\mathrm{mg} / \mathrm{kg}$ level. Lower scores for dahi fortified with iron at 20 and $30 \mathrm{mg} / \mathrm{kg}$ level which is due to the whey separation in samples.

\section{Influence of iron on haemoglobin, blood iron concentration in rats}

The effect of iron fortification on Haemoglobin, blood iron concentration in rats was studied and results are depicted in table 4 .

It is evident from the values of the table that, there was variation in haemoglobin, blood iron concentration in rats fed with control as well test diet. It is very much interested to note that there is a tremendous increase in blood iron $(46.25 \mathrm{mg} \%)$ concentrations in rats fed with iron fortified diet than in lab animals fed with either control $(35.82 \mathrm{mg} \%)$ or unfortified dahi (37.92mg \%).

Dahi made by using 1 percent starter culture showed uniform body and texture, optimum acidity with no whey separation. The increase in starter culture level resulted in increased acidity reflecting, increased sourness. Hence, dahi made by using $1 \%$ starter culture was employed for experimental studies. The sensory score revealed that possibility of making good quality dahi by fortifying milk with food grade ferrous lactate and dahi made from such fortified milk respectively at a level of $40 \mathrm{mg} / \mathrm{kg}$ milk, the resultant dahi was not differing than the control upon organoleptic evaluation. Hence, dahi fortified with ferrous lactate at an optimum level of $40 \mathrm{mg} / \mathrm{kg}$ is employed for the study. Over and above, this level of fortification the dahi samples exhibited metallic flavour. Fortification of dahi with iron salts at this rate had no noticeable effect on physico-chemical properties. In the present investigation, haemoglobin and blood iron was higher in rats which were fed with dahi fortified with 
iron (16.1\% and $46.25 \mathrm{mg} \%$ respectively) when compared to control, unfortified dahi. Which is an indication that iron fortified dahi can be used effectively to improve the bioavailability of iron to combat iron deficiency anaemia. This is due to the fact that binding iron to phosphoserine residues of low molecular weight milk protein peptides of dahi improved absorption and its ability to overcome iron deficient anaemic conditions.

\section{References}

Association of Official Analytical Chemistry (AOAC), 1980, Official methods of analysis. $13^{\text {th }}$ edn., Washington, D.C. 2044 pp 114.

El-Din, G, A. M., Hassan, A. S. H., EiBehairy, S. A. and Mohamed, E. A., 2012. Impact of zinc and iron salts fortification of buffalo's milk in the dairy product. World. J. Dairy. Food. Sci. 7: 21-27.

El-Kholy, A. M., Osman, M., Gouda, A. and Ghareeb, W. A., 2011. Fortification of yoghurt with iron. World. J. Dairy. Food. Sci. 6: 159-165.

Hossain, M., Fakruddin, M and Islam, N. M., 2012. Development of Fruit Dahi (Yoghurt) Fortified with Strawberry, Orange and Grapes Juice. Am. J. Food Technol., 7(9):562-570.

Kale, A.K., Dhanalakshmi, B and Kumar, U., 2011. Development of Value Added Dahi by Incorporating Cereal and Fruits. J. Food Sci. and Engineering, 1: 379-385.

Khedkar, C. D., Khedkar, G. D., Kalyankar, S. D., Bajad, D. N. and Sarode, A. R., 2003. Dahi. Encyclopedia of food sciences and nutrition, second edition. Academic press. 3: 1721-1725.

\section{How to cite this article:}

Priyanka, Anjum, C.S. Shashi Kumar and Narasimha Murthy. 2018. Effect of Fortified Iron in Dahi on Haematological Parameters in Rats. Int.J.Curr.Microbiol.App.Sci. 7(06): 103-108. doi: https://doi.org/10.20546/ijcmas.2018.706.014 